Originalveröffentlichung in: H.F.J. Horstmanshoff - H.W. Singor-F.T. van Straten - J.H.M. Strubbe (eds.), Kykeon. Studies in Honour of H.S. Versnel, Leiden-Boston-Cologne: Brill 2002, S. 23-48

\title{
RITUAL DYNAMICS: THE BOIOTIAN FESTIVAL OF THE DAIDALA
}

\section{Angelos Chaniotis}

\section{Sources and puzzles}

In Turkish folkore Nasreddin Hoca is a representative of popular wisdom; his stories are well-known in Greece as well. One of them goes as follows: Nasreddin Hoca had been appointed as a judge in a dispute between two men. After the plaintiff had presented his case, Nasreddin Hoca looked at him and said: 'You are right'. Then it was the defendant's turn to present his argument and, again, Hoca's response was the same: 'You are right'. Thereupon one of the onlookers at the trial turned to Hoca and said: 'You are the judge; you have to pass a judgment now'. Hoca looked at him calmly and answered: 'You are right, too'. Whenever I heard this story as a child, I laughed, but at the same time I was puzzled about its meaning. I still am, but I can not help thinking of this story whenever I read different interpretations of the same Greek festival. Of course, not everyone is right, but there is hardly any study which does not offer a new interesting insight. I also could not help thinking of Hoca's story again, when I read the jacket of the second volume of the Inconsistencies in Greek and Roman Religion. There, Henk Versnel expresses his conviction 'that the three approaches to religion known as "substantivistic", functionalist and cultural-symbolic respectively, need not be mutually exclusive.'

If I have chosen such a puzzling festival as the Daidala for this paper in honor of Henk Versnel, it is because I think that it presents an interesting case of a ritual, in the study of which different interpretative approaches are not mutually exclusive or contradictory, but complementary. John Ma (1994) has demonstrated this in a very witty way in his Black Hunter Variations, and Versnel himself has offered an illuminative example with his analysis of the Thesmophoria $(1994,228-288)$. At the same time the Daidala, with their long and complicated history, point to one of the reasons why different approaches in the study of Greek festivals are not only legitimate, 
but indeed necessary. Festivals known primarily or exclusively from late sources are the result of the natural and unavoidable tensions and conflicts between an inherently conservative element on the one hand and a very dynamic element on the other: between ritual actions, which have to be performed in a particular way, and the continually changing community of performers, participants, and receptors or spectators.

The earliest literary references to the Daidala date from the Imperial period. ${ }^{1}$ A fragment of Plutarch's treatise on this festival (Peri ton en Plataiais Daidalon) gives us two versions of the aetiological myth. A third version, but also a description of the (allegedly heptaeteric, but possibly annual) Small Daidala at Plataiai and the Pamboiotian Great Daidala (which were allegedly celebrated every sixty years) is given by Pausanias. ${ }^{2}$ I have summarized the two reports (see appendix) on the following table:

\begin{tabular}{|c|c|c|c|}
\hline Plutarch I & Plutarch II & Pausanias & Festival \\
\hline & $\begin{array}{l}\text { quarrel between } \\
\text { Hera and Zeus }\end{array}$ & $\begin{array}{l}\text { quarrel between } \\
\text { Hera and Zeus }\end{array}$ & \\
\hline $\begin{array}{l}\text { abduction of Hera } \\
\text { from Euboia }\end{array}$ & $\begin{array}{l}\text { Hera hides in } \\
\text { Kithairon }\end{array}$ & $\begin{array}{l}\text { Hera hides in } \\
\text { Euboia }\end{array}$ & \\
\hline \multicolumn{4}{|l|}{$\begin{array}{l}\text { hieros gamos in } \\
\text { Mt. Kithairon }\end{array}$} \\
\hline \multirow[t]{5}{*}{$\begin{array}{l}\text { Makris looks for } \\
\text { Hera, deception } \\
\text { by Kithairon }\end{array}$} & $\begin{array}{l}\text { advise of } \\
\text { Alalkomenes }\end{array}$ & $\begin{array}{l}\text { advise of } \\
\text { Kithairon }\end{array}$ & $\begin{array}{l}\text { selection of an } \\
\text { oak at } \\
\text { Alalkomenai }\end{array}$ \\
\hline & $\begin{array}{l}\text { construction of a } \\
\text { wooden image } \\
\text { (Daidale) }\end{array}$ & $\begin{array}{l}\text { construction of a } \\
\text { wooden image } \\
\text { (Plataia, daughter } \\
\text { of Asopos) }\end{array}$ & $\begin{array}{l}\text { construction of } 14 \\
\text { wooden images } \\
\text { (daidala) }\end{array}$ \\
\hline & & & $\begin{array}{l}\text { distribution of the } \\
\text { daidala among the } \\
\text { Boiotian cities }\end{array}$ \\
\hline & $\begin{array}{l}\text { decoration of the } \\
\text { image }\end{array}$ & $\begin{array}{l}\text { decoration of the } \\
\text { image }\end{array}$ & $\begin{array}{l}\text { decoration of the } \\
\text { image }\end{array}$ \\
\hline & $\begin{array}{l}\text { nuptial bath } \\
\text { (Tritonides) }\end{array}$ & & $\begin{array}{l}\text { nuptial bath at } \\
\text { Asopos }\end{array}$ \\
\hline
\end{tabular}

1 For possible earlier iconographical sources see Simon 1972; Avagianou 1991, 64f.

2 On the problems of the periodos of the festival see Nilsson 1906, 50f; Kirsten 1950, 2320; Schachter 1981, 249f; Prandi 1983, 84 and 89-91. 
(table cont.)

\begin{tabular}{|c|c|c|c|}
\hline Plutarch I & Plutarch II & Pausanias & Festival \\
\hline & $\begin{array}{l}\text { wedding song, } \\
\text { music, and komos }\end{array}$ & chariot & chariot \\
\hline & Hera's wrath & Hera's wrath & $\begin{array}{l}\text { the sequence of } \\
\text { the poleis is } \\
\text { determined by lot }\end{array}$ \\
\hline & $\begin{array}{l}\text { Hera comes to } \\
\text { Plataia followed } \\
\text { by women }\end{array}$ & $\begin{array}{l}\text { Hera comes to } \\
\text { Plataia }\end{array}$ & $\begin{array}{l}\text { procession to the } \\
\text { top of } \mathrm{Mt} \text {. } \\
\text { Kithairon }\end{array}$ \\
\hline & $\begin{array}{l}\text { Hera recognizes } \\
\text { the deception }\end{array}$ & $\begin{array}{l}\text { Hera recognizes } \\
\text { the deception }\end{array}$ & \\
\hline & laughter and joy & joy & \\
\hline & $\begin{array}{l}\text { reconciliation } \\
\text { wedding } \\
\text { procession }\end{array}$ & reconciliation & $\begin{array}{l}\text { reconciliation of } \\
\text { Thebes and } \\
\text { Plataia }\end{array}$ \\
\hline \multirow[t]{4}{*}{$\begin{array}{l}\text { Hera Teleia, } \\
\text { Gamelios }\end{array}$} & $\begin{array}{l}\text { Hera } \\
\text { Nymphagogos }\end{array}$ & $\begin{array}{l}\text { Hera Teleia, } \\
\text { Nympheuomene }\end{array}$ & \\
\hline & & & $\begin{array}{l}\text { construction of an } \\
\text { altar }\end{array}$ \\
\hline & & & $\begin{array}{l}\text { sacrifice of cows } \\
\text { and oxen }\end{array}$ \\
\hline & burning of Daidale & & $\begin{array}{l}\text { burning of the } \\
\text { daidala }\end{array}$ \\
\hline
\end{tabular}

The aetiological myths were meant to explain why Hera was worshipped as 'the marrying one' (Nympheuomene) and as the patron of marriage (Teleia and Gamelios). But only the first of the two myths narrated by Plutarch offers an explanation: when Hera was abducted by Zeus from Euboia, Kithairon provided them shelter and deceived Hera's nurse, telling her that Zeus was hiding there with Leto. The wedding of Zeus and Hera became known and then Hera was worshipped as Teleia and Gamelios. The problem is that this version does not seem to be related-at least not directly- to the Daidala. The two other versions are connected with the Daidala, but they narrate the quarrel and reconciliation of Hera and Zeus, not their wedding; a connection with the wedding of Hera can be established, only if one presupposes an interdependence of the motifs of virginity, wedding, and separation in the myths of Hera-a suggestion made by $M$. Jost in the light of the myths of Hera in Boiotia 
and Arkadia (Hera Pais, Teleia, Chera). ${ }^{3}$ Many scholars have pointed out that the ritual described by Pausanias has several features of a wedding ceremony: the decoration of a wooden image as a bride, the nuptial bath, a nympheutria, the wedding procession, the singing of wedding songs. ${ }^{4}$ And yet, the wooden image which represents a bride does not end up on the nuptial bed, but on the pyre; in addition to this, all the sources make clear that the wooden image did not represent Hera, as one would expect in the case of a hieros gamos, but either Plataia or Daidale. ${ }^{5}$ These are but a few of the problems which made M.P. Nilsson call the Daidala the strangest festival of Hera. ${ }^{6}$ But even this statement is not free of problems, since it implies that the Daidala was in fact a festival of Hera.

Amongst the many studies on the Daidala ${ }^{7}$ one recognizes, basically, two approaches: one of these places the ritual of the hieros gamos in the foreground; many scholars who have followed this approach regard the festival as described by Pausanias as a unity, offering different explanations for the obvious discrepancies between the Daidala and what one can expect from a celebration of a sacred wedding. ${ }^{8}$ The second approach recognizes the heterogeneity of the details described by Pausanias, but then focuses on the construction and burning of the wooden image or images, investing this ritual with a variety of meanings which range from the idea of an annual

${ }^{3}$ Jost 1997; see already Wilamowitz 1931, I 238.

4 See, e.g., Nilsson 1906, 51f; Kern 1926, 67; Kirsten 1950, 232 1; FrontisiDucroux 1975, 203f; Avagianou 1991, 60-62; Clark 1998, 23.

5 Nilsson 1906, 52-54; cf. most recently Pötscher 1987, 57f.; Jost 1997, 91; Clark 1998, 24f.; cf. Kerényi 1972, 114f., who thought, however, that originally the image represented Hera. On the contrary, Simon 1980, 59, maintains that the daidala carried in procession to Mt. Kithairon were in fact images of Hera.

${ }^{6}$ Nilsson 1906, 50: 'das merkwürdigste Herafest'.

7 I give a selection of the most influential and the most recent studies, in which one may find further bibliography: Farnell 1896, 189f; Nilsson 1906, 50-56; Kern 1926, 66-68; Wilamowitz 1931, I 239-242; Meuli 1946, 209-211; Kirsten 1950, 2321-2325; Jacoby 1955, 182f.; Sümeghy 1961; Nilsson 1967, 130f., 431; Kerényi 1972, 114-118; Simon 1972, 210-214; Frontisi-Ducroux 1975, 193-216; Burkert 1979, 132-134; Furley 1981, 201-210; Schachter 1981, 245-250; Prandi 1983; Pötscher 1987, 50-65; Burkert 1988; Loucas-Durie 1988, 155f.; Avagianou 1991, 59 68; Jost 1997; Simon 1997; Clark 1998, 22-26. The PhD dissertation of. H. Bacon Soule, The Cults of Plataea and the Daedala (Univ. of. California, Berkeley 1941) has not been accessible to me; Bacon Soule interpreted the Daidala as a celebration of the union of the goddess of the moon with the god of the sky (see Frontisi-Ducroux $1975,198 f$.$) .$

${ }^{8}$ See, in particular, Farnell 1896, 189f.; Kirsten 1950, 2321-2325; Sümeghy 1961, 129; Kerényi 1972, 114; Furley 1981, 203-210; Avagianou 1991, 59-68; Clark 1998, 24f. Cf., more differentiated, Nilsson 1906, 51-55. 
fire expressing the rejuvenation of nature to the appeasement of a mighty chthonic goddess. ${ }^{9}$ In recent research, almost all scholars agree that the rituals which were celebrated in the Imperial period present the result of amalgamations and artificial transformations, often under the influence of political factors, ${ }^{10}$ although there is no agreement in the efforts to trace the different origins of these components. "The following brief review of the most influential studies is more than mere doxography; I hope that it will be an instructive demonstration of the value of different approaches and of the problems of 'unitarian' interpretations, but also of the necessity to take into consideration the dynamic nature of rituals.

\section{The Daidala as a hieros gamos}

One strand of scholarship regards the Daidala as the ritual enactment of a sacred marriage, and, as already mentioned, it is difficult to deny the existence of such an element. The followers of this interpretation suggest, quite plausibly, that the protagonists of this hieros gamos were two deities of fertility, a god of the sky and an earth goddess that were later identified with Zeus and Hera. The problems begin, however, when one attempts to associate the holocaust with the sacred marriage. According to E. Kirsten $(1950,2322)$ the pyre is a necessary element of Zeus' epiphany, although he was unable to provide any parallels for this element in other festivals of Zeus. For W. Furley the great pyre on the top of the Kithairon is the wedding of the god of thunder with a goddess (Plataia/Daidale); the large altar recalls the construction of a building; it represents the oikos which one expects in a wedding; Furley recognized a parallel in the burning of Semele. ${ }^{12}$ A. Avagianou (1991, 64-67) suggested,

${ }^{9}$ See, e.g., Nilsson 1906, 50-56; Meuli 1946, 209-211; Schachter 1981, 247; Burkert 1988.

${ }^{10}$ Kerényi 1972, 114; Frontisi-Ducroux 1975, 199, 204; Schachter 1981, 248-250; Prandi 1983; cf. Furley 1981, 206 and 209; Clark 1998, 25.

$"$ See esp. Furley 1981, 206-210; Schachter 1981, 245; Prandi 1983, 86f.; KossatzDeissmann 1988, 666; Jost 1997, 9lf.; Clark 1998, 25. A characteristic example is E. Simon. Based on Meuli $(1946,209-211)$ she suggested $(1972,210)$ that rituals for a chthonic goddess were re-interpreted when Hera became the Olympian consort of Zeus (cf. Kossatz-Deissmann 1988, 666); later she postulated a conflation of two different perceptions of. Hera: an 'Achaean' Hera, patron of marriage, and a 'Pelasgian/Aeolian' Hera, a great mother goddess (Simon 1997).

${ }^{12}$ Furley 1981, 207. Cf. Farnell 1896, 190; Schachter 1981, 245. 
independently, that Semele was in fact Zeus' original bride: a chthonic goddess whose name possibly means 'earth' and whose grave was located on Mt. Kithairon. ${ }^{13}$ I very much doubt whether Semele's burning should be regarded as a conclusive parallel. Besides the fact that none of our sources refers to her (Jost 1997, 91), no sources indicate that her burning occurred during her first encounter with Zeus as a virgin; on the contrary, all the explicit sources assert that Semele's death occurred during her pregnancy. ${ }^{14}$ Thus, her death by burning cannot be perceived as the bride's consumption by fire, i.e., as a sacred marriage. There is a second difficulty; if Hera substituted Semele as the bride, then it is her image that one needs in the ritual enactment of the hieros gamos. But the daidala are clearly not images of Hera (see note 5) - and besides, the burning of images representing Olympian gods would be unparalleled in Greek festivals (Frontisi-Ducroux 1975, 207). It is for this reason that I. Clark (1998, 24f.) suggested that there is a missing section in Pausanias' description of the ritual and that, at some point, the false bride was ousted and her role as a bride was taken over by Hera; the wooden images were destroyed in an act of propitiation for Hera; this attractive suggestion cannot be proven. F. Frontisi-Ducroux, who has contributed one of the most intriguing studies of the Daidala, regarded the construction and the burning of the Daidala as integral part of the motif of deceit, which often accompanies narratives of sacred weddings $(1975,213-215)$. Still, this illuminative observation does not explain the treatment of the daidala as sacrificial objects.

Although this approach, which underlines the unity of the festival, fails to offer a satisfactory explanation of the Daidala's complex character, there can be little doubt that a hieros gamos was one of the festival's components; ${ }^{15}$ one can also not ignore the fact that the cultic epithets of Hera (esp. the epithet Nympheuomene) underline her role not just as a patroness of marriage, but in fact as a bride. We may even go a step further and suggest that in an early period a wooden image played some part in a ritual enactment and cele-

${ }^{13}$ Not only Semele has been associated with the Earth goddess, but also Plataia ('the wide one', i.e., the earth): see, e.g., Burkert 1979, 133; Pötscher 1987, 63. The Indian parallels of marriage through fire, mentioned by Avagianou, are not very helpful.

${ }_{14}$ Apollodoros 3.4.3; Ovidius, Metam. 3.253-309, esp. 260f.; cf. the iconographical sources in Kossatz-Deissmann 1994, esp. 725.

${ }^{15}$ Cf. Frontisi-Ducroux 1975, 203f.; Prandi 1983, 86f. 
bration of the sacred wedding of Zeus and Hera. The hieros gamos of Zeus and Hera was celebrated in many Greek cities. ${ }^{16}$ The ritual enactment of the wedding of Zeus and Hera is explicitly attested for Knossos, where it was celebrated near the river Theren, but we have no further information concerning the use of an image. ${ }^{17}$ But a wooden statue was the focal point of a celebration of Hera's wedding at the festival of the Heraia (rather than at the festival of the Tonaia) in Samos. ${ }^{18}$ On Kos we know the ritual dendrokopion tes Heras ('the cutting of a tree for Hera'); we do not know why a tree was cut for Hera, but it may have been used for the making of her image. ${ }^{19}$ Closer to Plataiai, in Thespiai, an image of Hera Kithaironia was a 'tree trunk', a premnon, ${ }^{20}$ and $\mathrm{E}$. Simon has suggested that the clay statuettes of a seated or standing goddess with a body like a plank of wood found in Boiotia are representations of wooden daidala of Hera. ${ }^{21}$ In Argos the priestess of Hera was brought on a chariot to the Heraion, probably as a nympheutria in Hera's wedding, rather than representing the goddes; Hera was possibly represented by an image (or an uniconical representation); on the right hand side of the pronaos of the Heraion stood a bed (kline), most probably one of the paraphernalia for her sacred wedding with Zeus. ${ }^{22}$ It goes without saying that the images were not burned on these occasions.

\section{The Daidala as a fire ritual of fertility}

A far more influential approach has its origins in Mannhardt's Baumkultus der Germanen and Frazer's Golden Bough. It associates the Daidala with the spring and mid-summer bonfire festivals of modern Europe

16 The most detailed treatment of the subject is given by Avagianou 1991, 27-73; cf. Simon 1972, 213f. and 1997, 84f.; Jost 1997, 88; Clark 1998. For the motif of the hieros gamos in the iconography of Hera see Kossatz-Deissmann 1988, 683-685; Avagianou 1991, 75-112.

17 Diodoros 5.72.4; cf. Avagianou 1991, 71-73; Chaniotis 1992, 87.

${ }^{18}$ Avagianou 1991, 46-58, esp. 54-58 (with the earlier bibliography). A decisive piece of evidence is the information of Varro (apud Lactantius, Inst. 1.17.8) that a statue of Hera in Samos was dressed with a wedding dress.

${ }^{19}$ Nilsson 1906, 61, with reference to the source. Nilsson thought, however, that the dendrokopion was related to the cult of Hera as a goddess of vegetation.

${ }^{20}$ Clemens Alexandrinus, Protr. 3.46.3; cf. Nilsson 1906, 53; Schachter 1981, 251.

2) Simon 1972, 210-218; Simon 1980, 58f.; cf. Schachter 1981, 244; Prandi 1983, 9lf.; for criticism see Pötscher 1987, 50-57.

${ }_{22}$ Pausanias 2.17.3; Avagianou 1991, 36-45, esp. 41-43; Simon 1997, 84. 
(of the Maypole or Johannesfeuer-type), at which a wood-en image is brought to the settlement and burned. According to J.G. Frazer's interpretation, the Daidala represent the marriage of powers of vegetation (Frazer 1913, 140f); Hera's retirement is a mythical expression for a bad season and the failure of crops. M.P. Nilsson speculated that the image which was burned represented a demon of vegetation that had to go through fire in order to secure the warmth of the sun for everything that lives and grows; since this fire ritual intented to promote fertility it was understood as a wedding; Hera was associated with this festival at a late stage, as the goddess of marriage; the discrepancies in the myths and the rituals reflect the late conflation of two separate festivals, a fire festival and a festival of Hera. ${ }^{23}$ The prominent position of a holocaust offering at two festivals of Artemis, the Laphria and the Elaphebolia, has led A. Schachter to the assumption that, similarly, the burning of the images at the Daidala was originally dedicated to Artemis and at some later point connected with the cult of Hera; for 'it would need little special pleading to combine with the worship of the patroness of marriage that of the patroness of childbirth. ${ }^{, 24}$ But the similarity between the Daidala on the one hand and the Laphria and the Elaphebolia on the other is rather superficial (Jost 1997, 91); the burning of slaughtered sacrificial victims at the Daidala cannot be compared with the throwing of living animals into the pyre at the Laphria. In addition to this, I can see no evidence for the assumption that in the holocausts of the Laphria and the Elaphebolia Artemis was conceived as the patroness of childbirth; and of course, there is no evidence for the sacrificial burning of wooden images in these festivals of Artemis (cf. below).

W. Burkert's interpretation along the same lines presents the most significant progress in the interpretation of the Daidala in recent years. ${ }^{25}$ In the light of some ancient parallels he has attributed the Daidala to a category of festivals and Oriental myths the common theme of which is the departure and return of a goddess of fertil-

${ }^{23}$ Nilsson 1906, 54f.; Nilsson 1967, 130f., 431; cf. Nilsson 1923, 144; Kern 1926, 66-68. Cf. the extremely confusing remarks of Kirsten 1950, 2322f.

${ }^{24}$ Schachter 1981, 247. Already Meuli $(1946,209)$ had associated the Daidala with the Laphria, but as examples of chthonic sacrifices. But see Frontisi-Ducroux 1975, 205-207.

${ }^{25}$ Burkert 1988; cf. Burkert 1979, 132-134; 1985, 63. 
ity. Burkert recognized an ancient Greek parallel in a representation on a pithos of the 9th cent. BC found at Knossos (Fig. 1). A winged goddess, richly dressed and with a high polos, stands on a chariot. ${ }^{26}$ She is represented in two different ways in two panels on the two opposite sides of the pithos. In the one panel (Fig. la) the goddess raises her hands on which two birds are seated. On the other panel (Fig. 1b) the goddess has dropped her arms, her wings are lowered, the birds fly away. The trees in the first representation blossom, the trees on the other side do not. According to Burkert's plausible interpretation, the two panels are connected with a festival of the coming and the departure of the great goddess of fertility; the chariot implies that an image of the goddess was brought into the city. There are indeed obvious analogies to the myths and the ritual of the Daidala: the departure of an (angry) goddess and her return, the carrying of an image on a chariot. But there are also obvious differences: the representation from Knossos is the image of a goddess; the wooden daidala were not; the daidala were burned; and there is no indication that the image on the Knossian pithos is that of a bride.

Another parallel was recognized by Burkert in the report of Firmicus Maternus concerning a festival of Persephone (Err. prof. rel. 27.2). A tree was cut and was used for the construction of the image of a maiden, which was then brought to the city; there, it was mourned for forty days; on the evening of the fortieth day, the image was burned. This ritual is supposed to reflect the annual cycle of nature. The joy at the coming of the goddess was followed by the sadness at her departure in the fall. Again, the differences from the Daidala are no less striking than the similarities. Persephone's periodical death finds no analogy in any known cult of Hera; the wooden daidala were not brought to the city, they were not mourned, and they were not supposed to represent the periodical death of a virgin. Ailianos (NA 4.2; VH 1.15) and Athenaios (394 b) have reports of a similar festival at Eryx, this time for Aphrodite-the festival Anagogia. It owed its name to the departure of Aphrodite, who was supposed to leave for Africa, followed by birds (pigeons). Nine days later a very beautiful pigeon was seen coming from the south, and its coming was celebrated as the festival Katagogia. We observe, however, that

\footnotetext{
${ }^{26}$ For the motif of the goddess on the chariot cf. already Sümeghy 1961 .
} 

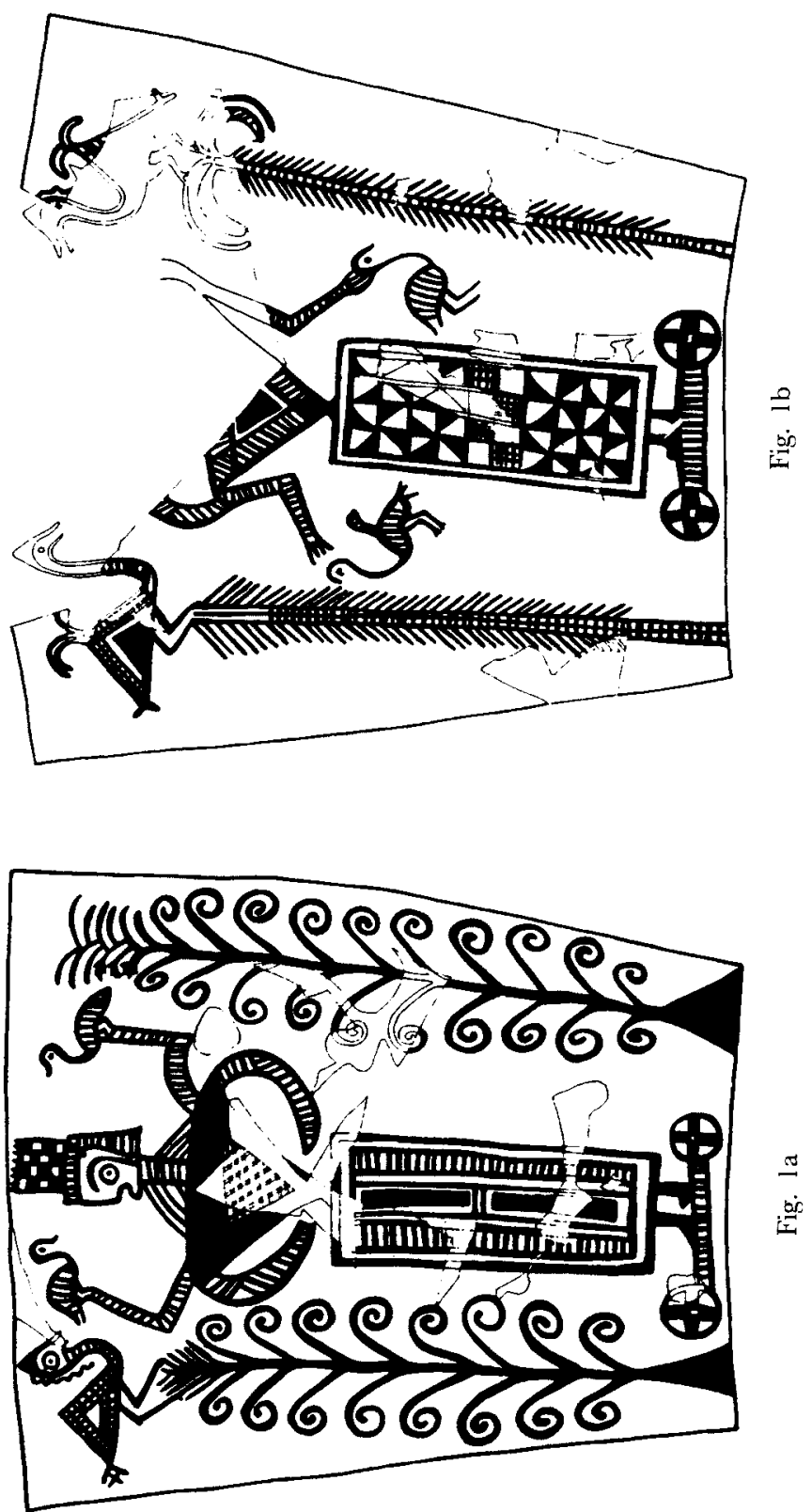
in this festival there is no image, no marriage, no pyre. Burkert suggested associating this group of festivals with mankind's primordial fears: Threatened by draught, bad harvests, infertility and bad weather, people leave from time to time the area of agricultural activity and return to the forest, where they used to find food at the stage of hunters and food collectors. The burning of an image may be a survival of the great pyres on peak sanctuaries in Minoan Crete; Burkert also observed that the Linear B texts of Knossos mention a Daidaleion. Despite the fact that the affinity between the Daidala and the fire rituals of Minoan Crete can only be a matter of speculation and although we do not know if the Knossian daidaleion was a sanctuary of Daidalos/Daidale or a place where daidala were kept, nevertheless, Burkert's assumption of a very old origin of the Boiotian Daidala seems quite probable. The role of Euboia in the aetiological myth seems to reflect a very early tradition, since the period of the Linear $B$ texts of Thebes in the Late Bronze Age is the historical period in which Euboia was most closely associated with Boiotia. ${ }^{27}$ Burkert's observations offer a conclusive explanation for the representation on the Knossian pithos and make clear that there existed a group of festivals celebrating the periodical departure and return of a goddess of fertility. Some elements of the Daidala have a close correspondence to this category of festivals, others do not.

\section{The Daidala as a sacrifice}

Modern research has not only isolated these two important components of the Daidala - the sacred marriage and the fire ritual; it has also pointed out that the burning of the Daidala can be conceived of as a sacrifice, and this is a very important element which is difficult to reconcile with the other two approaches. K. Meuli has assigned the sacrifice of the Daidala to the category of the 'chthonische Vernichtungsopfer', i.e., sacrifices offered to chthonic deities whose dangerous power should be appeased; the myth about the quarrel between Hera and Zeus and the goddess' withdrawal can be associated with this interpretation, ${ }^{28}$ which, however, fails to explain other

${ }^{27}$ For Euboian place names in the Mycenean texts from Thebes see Aravantinos 1987. For the early origin of the Daidala of Simon 1997, 85, who postulates a hieros gamos of Zeus and Hera as 'une sorte de dogme de la religion mycénienne'.

24 Meuli 1946, 209f. Followed by Kossatz-Deissmann 1988, 666. 
components of the ritual in the Imperial period (especially the allusions to a wedding). The fact that the daidala cannot be conceived as divine images led E. Loucas-Durie to the assumption that their burning was the substitute of a human sacrifice, which may have constituted a central part of the ritual in its early phase. ${ }^{29}$ In this context one should also mention a suggestion made by W. Pötscher (1987, 60): the daidala may have represented harmful powers and their expulsion from the city (which is, however, not mentioned in any source), their transportation to the mountain and their destruction aimed at removing harmful powers and pollution. The offering of an expiatory sacrifice can be plausibly brought into connection with agrarian rituals and with the hope of appeasing a mighty goddess and securing the fertility of the crops and the animals, ${ }^{30}$ such an expiatory character could also explain the irregular intervals in the celebration of the festival.

Not unlike the two other interpretations, the understanding of the Daidala as a sacrifice-and more specifically, as an expiatory sacrificedoes not explain all the details of the aetiological myths and their rituals; in particular, it is hard to explain how an expiatory sacrifice was transformed into a festival of Hera and how elements which recall a sacred marriage were introduced into this celebration. And yet, I think that there can be little doubt that an expiatory sacrifice was one of the components of the Daidala. Besides the fact that holocaust sacrifices often possess the character of expiatory sacrifices (e.g., Stengel 1910, 92-101), the construction and the treatment of the daidala recalls the selection and treatment of sacrificial animals. The Plataians cooked meat-Pausanias' vocabulary implies that it

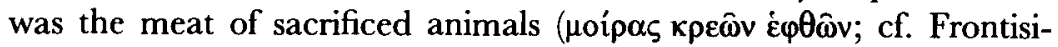
Ducroux 1975, 201 note 20)- and put it near a grove at Alalkomenai; priests or other officials waited there and observed the raven that would take this piece of meat. The tree where the bird came to rest was selected for the construction of the wooden image. This procedure seems at first sight to be a case of oionoskopia, ${ }^{31}$ but a closer

${ }^{29}$ Loucas-Durie 1988, 156; cf. tentatively Frontici-Ducroux 1975, 206-212. Rejected by Jost (1997, 90 note 31) without any further discussion. Bonnechere 1994, has not discussed this case.

${ }^{30}$ Cf. Simon 1997, 85f., based on Meuli's observations and the study of Y. Béquignon on the agrarian character of the fire ritual on Mt. Oete (Béquignon 1937, esp. 216-219); cf, Nilsson 1967, 130f.

${ }_{31}$ Nilsson 1906, 51, speaks of a 'Vogelorakel' (cf. Kossatz-Deissmann 1988, 666). 
look reveals its similarities with the selection of a sacrificial animal. A well-known procedure is the one described by Theophrastos (apud Porphyrios, Abst. 2.28-30) with regard to the festival of the Dipolieia (Burkert 1983, 137f.). A group of oxen was driven up on the Acropolis, where a cake (pelanos) was placed on a table; the ox which first ate the grain cake was sacrificed. In both cases specially prepared food was used as bait, with the help of which one selected the ox which would be sacrificed or the tree which would be used for the making of a daidalon. We may follow the parallelism one step further. The sacrificial animal is expected to excel in beauty and size. ${ }^{32}$ In the case of Daidala, the selection takes place in the grove with the

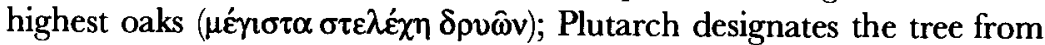

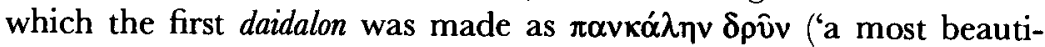
ful oak'), using an expression which recalls the designation of sacrifical animals (kallisteia, cf kallhierein). ${ }^{33}$ Finally, the daidalon shares the same destiny with a sacrificial animal. It is not a cult statue, it is not even supposed to represent a goddess. It is washed and adorned in order to be burned on an altar. The daidala were sacrificed ( $\alpha \boldsymbol{\theta} \theta \alpha \gamma_{i} \zeta$ ovouv

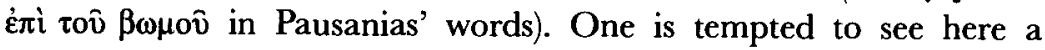
sacrifice of propitiation which recalls, e.g., the sacrifice of Iphigeneia, the king's daughter (cf. Plataia, the daughter of king Kithairon) who dressed as bride walks to her death to atone for her father's sacrilege. The treatment of the daidala is characterized by an ambivalence which has been observed in mythological reflections of scapegoat rituals (e.g., the myth of Polykrite of Naxos): something selected because of its beauty is decorated and cast out and destroyed as threatening and harmful. ${ }^{34}$ To regard the burning of the daidala as a transformation of a pharmakos ritual is perhaps too speculative, but the evidence that this ritual was conceived as a sacrifice is compelling; that the sacrifice had a propitiating or expiatory character is suggested both by its form (holocaust) and its aetiological myth (appeasement of Hera).

32 Burkert 1985, 56.

${ }^{33}$ E.g. Sokolowski 1962, no. 4l L. 23f.: $\alpha \hat{\gamma} \gamma \alpha \kappa\left[\alpha \lambda \lambda_{1}\right] \sigma \tau \varepsilon v ́ o v \tau \alpha$; Sokolowski 1969,

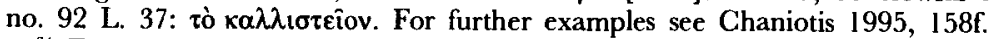

${ }^{34}$ For this ambivalence see Burkert 1985, 84; for the conflation of ideas of human sacrifice and scapegoat rituals (pharmakos) cf. ibid. and Bonnechere 1994, 303f. 


\section{The Daidala as a celebration of Boiotian unity}

Sacred marriage, departure and return, fire ritual, and expiatory sacrifice are still not the only components of the Daidala in the form the festival was celebrated in the Imperial period. The festival's political nature is prominent in Pausanias' report and has not escaped the notice of modern scholarship, especially of A. Schachter and L. Prandi (see note 10). An elaborate reconstruction of the 'political' history of the Daidala, has been suggested by L. Prandi: the Daidala represent the amalgamation of a ritual at Alalkomenai, in which the daidala were perceived as a symbol of fertility, of a sacred wedding celebrated on the Kithairon, in which Hera must have had a predecessor (Leto?), and of the cult of Hera; at some point of its history, Plataiai was able to take under its patronage this Pamboiotian festival; this evolution may indeed be reflected by the relevant aetiological myths, especially by the role of Leto and by the replacement of Alalkomenes, as the wise advisor of Zeus, by Kithairon. ${ }^{35}$ Clark $(1998,25)$ has plausibly recognized in the Daidala, in the form it was celebrated from the late Classical period onwards, an expression of the political and cultural identity of Plataiai and the cities of Boiotia.

There can be no doubt concerning the festival's political nature, which can be observed also in small details. First of all, Pausanias makes clear that the quarrel and reconciliation of Zeus and Hera had presented the mythological exemplum for the reconciliation of Thebes and Plataiai in the late 4th century BC; in his words: 'for the Thebans too (kaì ovitor) wanted to reconcile themselves with the Plataians.' The words xoi ovitor make sense only in the context of another reconciliation mentioned earlier, i.e. the reconciliation of Zeus and Hera. Furthermore, the mode of distribution of the fourteen daidala among big and small poleis - with eight big poleis receiving one daidalon each, the smaller poleis sharing six images-corresponds roughly to the mode of the appointment of the Boiotarchs in the Boiotian Koinon of the late 4th cent. BC, with Tanagra appointing one, Thespiai and Orchomenos sending two, six small cities sharing another two, and Thebes appointing four Boiotarchs. ${ }^{36}$ Another

${ }^{35}$ Prandi 1983, 86-94. Cf. Jost 1997, 91.

${ }^{36}$ Roesch 1965, 47. Roesch 1965, 104 has suggested that the list of the participants at the Daidala includes the cities which had the right to elect one of the 
feature of a political nature is the propompeia, i.e., the sequence of the representatives in the procession. Processions which take place under the participation of different groups confront them with the question about who is going to lead the pompe. In the Eleutheria of Plataiai the decision was taken at the dialogos, the rhetorical competition between the representatives of Athens and Sparta (Robertson 1986); at Bargylia, during the festival of Artemis Kindyas, the tribe which had raised the most beautiful cow received this honor (SEG XLV 1508 A LL. 6-9). At the Daidala, this decision was taken by lot. These elements must have been added to the celebration in the course of an artificial reorganisation of the festival as a Pamboiotian festival in the Classical or Hellenistic period. In fact, the Daidala must have been the object of articifial reorganisations several times in their history, not least because of important political events which must have affected the cult of Hera at Plataiai and either interrupted the celebration of the festival (cf. Pausanias 9.3.5) or changed the city which was in charge of the celebration; such events were the Persian Wars (479 BC), the Theban victory in $426 \mathrm{BC}$, and the refoundation of Plataiai in $386 \mathrm{BC}^{37}$ It goes without saying that such elements as the Pamboiotian unity or the motif of interstate reconciliation, which the Daidala reflected from the Hellenistic period onwards, were not part of the festival's original meaning.

\section{Putting the pieces together}

Let me summarize the results of this analysis. The discrepancies between myths and ritual and the incompatibility among the various rituals which were part of the Daidala in the Imperial period

federal magistrates, the aphedriateuontes. But see Prandi 1983, 92 note 37 . As Schachter (1981, 248f.) has pointed out, the list of participant towns reflects the situation in the 1 st and 2 nd cent. $\mathrm{AD}$, but the number of the 14 daidala may well be traditional. Cf. Prandi 1983, 92f.; Jost 1997, 91.

${ }^{37}$ For these events and their effect on the cult of. Hera see Prandi 1983. One (minor) reorganisation can be dated with certainty to ca. 317 or $315 \mathrm{BC}$, when Thebes was allowed to participate in the festival (Schachter 1981, 247f;; Prandi 1983, 89). I tentatively suspect a further reorganisation in ca. 220 , in a period in which several Pamboiotian festivals were reorganised (see more recently Nafissi 1995; Knoepfler 1996), but there is no evidence for this assumption. The absense of two important Hellenistic cities (Haliartos and Akraiphia) may imply a further change in the distribution of the daidala in the Imperial period (cf. Schachter 1981, 248f.). 
suggest that the celebration described by Pausanias and the myths narrated by him and by Plutarch present the result of amalgamations and artificial transformations. We may tentatively identify three separate pre-Classical sources for the rituals which later constituted one single festival:

1. In Plataiai, as in other parts of Greece, a hieros gamos of Hera and Zeus was celebrated. Traces of this ritual are still recognizible in the epikleseis of Hera, in the first version of the aetiological myth, and in the joint sacrifice offered to Zeus and Hera on Mt. Kithairon. A wooden image may have been used for this celebration. In that case, the archaic statuettes of Boiotia ('Brettidole') with bridal features are representations of Hera, as assumed by $\mathrm{E}$. Simon (see note 49 ), but they related to a celebration of her sacred marriage and not to the holocaust on Mt. Kithairon. Since marriage, departure, and return of Hera seem to constitute a unity in the aetiological myths, the idea of the periodical departure and return of a goddess of fertility may have been connected with this sacred marriage at some point.

2. A separate ritual consisted in the construction and the burning of a wooden image or images. Several elements of the festival recall fire rituals, which according to recent research were associated with fertility.

3. There are strong indications that yet another separate fire ritual, probably repeated at irregular intervals, had the character of a propitiatory sacrifice. It may have included the ritual enactment of the sacrifice of the daughter of a king, dressed as a bride, in order to appease a goddess' wrath. A wooden image, a daidalon, may have been used for this ritual enactement as well.

In historical times the festival had a predominantly political character. The motif of reconciliation had overshadowed other motifs (fertility, sacred wedding, and atonement). The troubled history of Plataiai resulted in several interruptions and reorganisations of these celebrations, which in the end were combined into one.

\section{Ritual dynamics in Greek festivals}

The Daidala are not the only Greek festival which demonstrates such a complex overlapping of heterogenous and sometimes contradictory elements. We may observe similar (perhaps less complex) phenomena in the case, e.g., of the Athenian Oschophoria and Pyanopsia or 
the Spartan Hyakinthia to mention but a few. In the Classical period the Oschophoria combined the cult of Dionysos with that of Athena Skiras and with an aetiological myth connected with Theseus, as the prototype of the Athenian ephebe; it combined elements of initiatory transvestism with those of a festival of viticulture ${ }^{38}$ The Pyanopsia, originally an agrarian festival to judge by its name, had become a festival of Theseus. ${ }^{39}$ The Hyakinthia of Sparta combined in the course of its history so many elements, that modern scholarship did not have any difficulties in interpreting it variably, as a chthonic, initiatory, agrarian, or new year festival. ${ }^{40}$ These transformations are result of the tensions between traditional ritual actions, which have to be performed in a particular way, and continually changing communities of performers, participants, and receptors or spectators that invest the rituals with new meanings.

The mechanisms of transformation, reinterpretation, and association of rituals are sometimes easier to recognize than in others. The changes which are best documented are those of a political nature. ${ }^{41}$ The cause of the change may often be rather coincidental. E.g., the fact that a political event occurred on the day of an already existing festival may transform it radically (Chaniotis 1987, 136). In Athens, the festival of Artemis Agrotera became a commemorative historical anniversary of the battle of Marathon which had taken place on the festival's day (Parker 1996, 153). Dionysos Lysios in Eretria was worshipped as the patron of the city's freedom because the city was liberated on the day of a procession for the god (Jaccottet 1990). Sometimes social changes, more difficult to detect and date accurately, result in a change of a festival's function. The Athenian Thargelia offer a very instructive case. The predominant rituals of their celebration were the offering of first-fruit to Apollo and a scapegoat ritual. In the Classical period the festival was celebrated by the

${ }^{38}$ See esp. Jeanmaire 1939, 338-363; Deubner 1966, 142-147; Calame 1990, 143-148, 324-348; cf. Parker 1996, 308-311, and Waldner 2000, 102-154 with further bibliography.

${ }^{39}$ Cf. Deubner 1966, 198-201; Calame 1990, 150-153, 291-324.

${ }^{40}$ See esp. Nilsson 1906, 129-140; Jeanmaire 1939, 526-530; Brelich 1969, 141-148, 177-207; Bruit 1990; Brulé 1992; Pettersson 1992, esp. 9-41; Kennell 1995, 64-67. A problem of modern research on the Hyakinthia (of Pettersson's treatment in particular) is that it focuses on the Spartan evidence, ignoring the fact that this festival was widely celebrated. For another example of the conflation of rituals of different origins, the Daphnephoria at Thebes, see Prandi 1983, 88f

${ }^{*}$ Cf. Parker 1996, 267-275, for late Classical and Hellenistic Athens. 
phratries and was dedicated to Apollo Patroios; as the role of the phratries declined in the Hellenistic period, the god's epithet was somehow reinterpreted and associated with the achievement of the forefathers (progonoi) and the fatherland (patris). A decree which concerns the reorganisation of the festival in $129 / 128 \mathrm{BC}$ applies the words patris and progonoi seven times in 18 lines, focusing on military victories and glorious deeds. ${ }^{42}$ Social changes make some festivals (e.g., festivals related to initiation) obsolete, but some of their ritual acts may survive as parts of another festival. The initiatory transvestism at the Oschophoria in Athens may be such a survival. ${ }^{43}$ Finally, in some cases we may assume that the increasing popularity of a divinity (e.g., Dionysos) or a hero (e.g., Theseus) not only overshadowed festivals which were celebrated in the same month, but also integrated them into their celebrations. This is how we may explain the concentration of festivals connected with Theseus in Athens in the Pyanopsion, festivals which originally seem to have had other patron gods. ${ }^{44}$

I suspect that the different explanations given by ancient authors of the names of festivals or ritual phrases are due to changes in their perception, which then lead to misunderstandings and reinterpretations of names, divine epithets, and ritual phrases. The Athenian festival of the Anthesteria offers us an instructive example. The ancient literary tradition gives us two versions of the phrase which allegedly

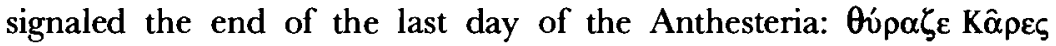

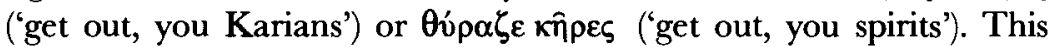
is not the place to discuss the controversial question whether the Athenians chased away the souls of the dead or mummers recalling Attica's aboriginal inhabitants, but it is at least certain that the interpretation of this day as celebration of a 'verkehrte Welt' postdates the importation of Karian slaves in Glassical Athens. ${ }^{45} \mathrm{~A}$ change in

42 Sokolowski 1962, no. 14 LL. 2-20; cf. Chaniotis 1995, 153f. On the Thargelia see Deubner 1966, 179-198; Burkert 1979, 59-77; Calame 1990, 308-319; Lambert 1998, $216 f$.

${ }^{43}$ For initiatory transvestism, in general, see more recently Leitao 1995. For transvestism at the Oschophoria see Jeanmaire 1939, 352-356; Calame 1990, 145.

${ }^{44}$ Cf. Calame 1990, 125-184; Parker 1996, 168-170.

45 Souls of the dead: e.g., Deubner 1966, 113f.; mummers recalling Attica's aboriginal inhabitants: Burkert 1983, 226-230. Bierl 1994, 32-36 (with the earlier bibliography), correctly observes the liminality of. these groups and also of. the Karian slaves. 
the perception of one of the oldest and most widespread Greek festivals, the festival of Demeter Thesmophoros, may also be responsible for the controversy which existed already in antiquity with regard to its name. ${ }^{46}$ According to Cornutus' view, which most modern scholars share, Thesmophoros characterized Demeter as the law-giving goddess; ${ }^{47}$ but others interpreted the thesmoi as the 'things laid down' ${ }^{48}$ In this context I am not concerned with the question which of the two meanings is the original one; what matters here is the fact that such controversies and misunderstandings were possible.

How and why different early celebrations, a sacred wedding, a fire ritual, a festival of Hera, and an expiatory sacrifice were associated in one festival - our Daidala of the historical period - can only be a matter of speculation. One might suspect that this conflation of different sources was made possible because of the association of all these rituals with ideas of fertility, but there is a far more simple (and possibly more plausible) explanation: the factor which played the most important part in this development was not the common meaning or the common function of different rituals, but a superficial similarity, a common detail of all these rituals: the use of wooden images. A wooden image could have been used in a hieros gamos (as in Samos); we know of a wooden image of Hera in Tanagra in Boiotia, and if the archaic statuettes of Boiotia ('Brettidole') are correctly identified with representations of wooden images of Hera, it is noteworthy that they have bridal features. ${ }^{49}$ Therefore, they may reflect the use of a wooden image in this celebration. A wooden image (daidalon) was also used in the celebration of the annual coming and departure of a goddess of fertility, as W. Burkert has demonstrated; wooden images were burned in fire rituals and possibly in substitute sacrifices of a propitiatory character. As these separate celebrations were often interrupted-sometimes for long periods of time - due to the troubled history of Boiotia and Plataiai, it should

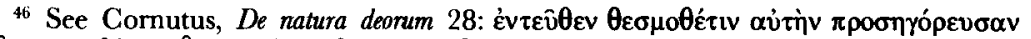

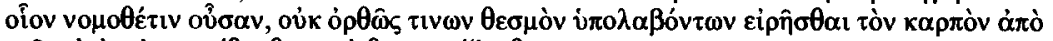

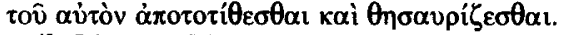

${ }^{47}$ Cf., e.g., LSJ, s.v.; Detienne 1989, 129. For thesmos, as the earliest Greek term for law see Gschnitzer 1995.

48 According to Nilsson (1906, 324; cf. Deubner 1966, 44f.) these thesmoi were the secret things laid in the megara (piglets, cakes, etc.) and then carried during the festival.

49 Simon 1972, $213 f$. 
not be surprising if their original meaning and function blurred in the course of time. But the memory and the popularity of such spectacular celebrations, involving processions, music, dances, and bonfires, must have remained vivid. The wooden images were always there, in all these celebrations, and they became the joining link of the different rituals. It was this element - the most popular and the most spectacular - that finally gave the outcome of the gradual amalgamation of rituals its name: the Daidala. Then it was the job of the mythographers and the exegetai to make sense of all this. ${ }^{50}$

I should mention an important objection to this scenario. William Furley $(1981,203)$ has pointed out that an explanation which is 'entwicklungsgeschichtlich' in type fails to explain how the paradox of the burning of a 'bride' and the role of Hera as a nympheutria and not nympheuomene could be sustained and remain meaningful at any one performance of the festival. I think that such a question can only be asked by historians of religion, exegetes, or foreign spectators, and not by the celebrants of festivals. Agatharchides narrates a very instructive anecdote which incidentally concerns, again, Boiotia: ${ }^{51}$ 'The Boiotians sacrifice to the gods those eels of the Kopaic Lake which are of surpassing size, putting wreaths on them, saying prayers over them, and casting barley-corns on them as on any other sacrificial victim; and to the foreigner who was utterly puzzled at the strangeness of this custom and asked the reason, the Boiotian declared that he knew one answer, and he would reply that one should observe ancestral customs, and it was not his business to justify them to other men' (transl. by G.B. Gulick, modified).

The Daidala confront us with questions that we cannot answer with certainty. And yet this festival, with its complicated structure and the coexistence of heterogenous elements, presents an instructive case of a festival with many overlapping layers of rituals, which

50 Cf. Jost 1997, 92. The late and artificial creation of the aetiological mythos is demonstrated by their protagonists, who are personifications of topographical elements of Boiotia: Kithairon, the wise advisor, is the high mountain on the top of which the festival was celebrated; the father of the 'bride', Asopos, is the local river; the adviser in another version, Alalkomenes, is named after the small town of Alalkomenai, which provided the tree for the construction of the daidala; the flutists and the dancers were provided by the personification of Boiotia; and one of the mythical brides, is Plataia herself, which may be an old name of the Earth goddess (see above, note 13).

${ }^{51}$ FrgrHist 86 F 5 (apud Athenaios VII 297d/e). I owe this reference to Dr. J. Mylonopoulos. 
came together in the course of a long development. Despite their conservative character (paradoxically, because of their conservative character) rituals are a very dynamic cultural phenomenon. Their conservative character obliges a community to fulfill them in a particular form, generation after generation. But in the course of time, and as the conditions change, functions and meanings become blurred and rituals adapt themselves to continually changing environments. The anecdote of Agatharchides demonstrates that a ritual was performed not because of its original meaning, which was obviously forgotten, but because of the importance attached to the preservation of ancestral traditions, thus assuming a new, 'patriotic' meaning. We have already seen that the predominant motif in the Daidala of the Imperial period was that of conflict and reconciliation and the promotion of local identity (cf. notes 10 and 35).

Exactly the blurring of meanings and the misunderstanding of their performance permits reinterpretations and new associations. Ancient philosophers were puzzled about whether Theseus' ship remained the same even though its rotten wooden components were continually being replaced. Festivals somehow confront us with a similar problem. Do ritual actions remain the same when their performers and receptors change? Being a historian of law and society I can only give a negative answer. Our efforts to find overall explanations of rituals and above all our natural fascination with the quest of origins should not overshadow an elementary truth: that even when ritual actions remain unchanged, the rituals as 'language' and communication (cf. Graf 1997) still change simply because of the fact that their performers and their receptors differ. It is for this reason that the application of different methods in the study of festivals is not only legitimate, but also necessary. Changing the phrase of a famous philosopher one might say, rather provocatively, that 'one cannot celebrate the same festival twice'.

\section{Appendix: The sources}

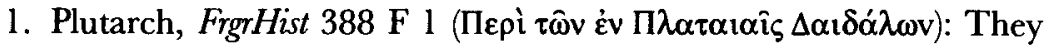
narrate that when Hera was being raised in Euboia she was abducted by Zeus, while she was still a virgin; she was brought here [to Boiotia] and hidden; Kithairon provided them with a shady hidden corner (mychos) and a natural chamber (thalamos). When Makris, Hera's nurse, 
came here looking for Hera and wanted to search for her, Kithairon did not allow her to take any trouble about it and did not lead her to the hiding place, claiming that Zeus was resting and staying there with Leto. Thereupon Makris left and Hera escaped in this way. Later, in grateful memory of Leto, Hera gave her (Leto) a share in her altar and in her temple, so that Leto Mychia receives a sacrifice (prothysia) as well; but other people call her Nychia; at any rate, both epithets remind of Hera's hiding and escape ... After the marriage [of Hera and Zeus] had become known and because their intercourse had been revealed for the first time near Kithairon and near the city of Plataia, they gave Hera the name Teleia and Gamelia ... But perhaps I should also narrate the more simple myth as well. They say that when Hera had quarreled with Zeus and was not willing to stay in the same place and was hiding, Zeus was wandering around helpless until he met the authochtonous Alalkomenes. Alalkomenes advised him to deceive Hera and to do so as if he would marry another woman. With Alalkomenes' help Zeus cut secretly a big and very beautiful oak tree, he gave it the shape of a woman, decorated it as a bride and called it Daidale. Then they sang for her the wedding song, the nymphs of the river Triton gave her the nuptial bath, and Boiotia provided for flutists and revellers. When all this was almost completed, Hera lost her patience. She came down from Mt. Kithairon, followed by the women of Plataia, and ran full of anger and jealousy to Zeus. But when she realised, that it was a doll, she reconciled herself with joy and laughter with Zeus and took the role of the bridesmaid. She honored this wooden image and named the festival Daidala. Nonetheless, she burned the image, although it was not alive, because of her jealousy.

2. Pausanias 9.2.7-9.3.3: There is at Plataia a temple of Hera, worth seing for its size and for the beauty of its images... The Hera they call Teleia (Married); it is an upright image of huge size... Here too is another image of Hera; it is seated, and was made by Kallimachos. The goddess they call the Nympheuomene (Bride) for the following reason. Hera, they say, was for some reason or other angry with Zeus, and had retreated to Euboia. Zeus, failing to make her change her mind, visited Kithairon, at that time ruler in Plataia, who surpassed all men for his cleverness. So he ordered Zeus to make an image of wood, and to carry it, wrapped up, in a bullock wagon, and to say that he was celebrating his marriage with Plataia, the daughter of Asopos. So Zeus followed the 
advise of Kithairon. Hera heard the news at once, and at once appeared on the scene. But when she came near the wagon and tore away the dress from the image, she was pleased at the deceit, on finding it a wooden image and not a bride, and was reconciled to Zeus. To commemorate this reconciliation they celebrate a festival called Daidala, because the men of old time gave the name daidala to wooden images...

So the Plataians hold the festival of the Daidala every seventh year, according to the local exegetes, but really at a shorter interval. I wanted very much to calculate exactly the interval between one Daidala and the next, but I was unable to do so. In this way they celebrate the festival. Not far from Alalkomenai is a grove of oaks. Here the trunks of the oaks are the largest in Boiotia. To this grove come the Plataians, and lay out portions of boiled flesh. They keep a strict watch on the crows which flock to them, but they are not troubled at all about the other birds. They mark carefully the tree on which a crow settles with the meat it has seized. They cut down the trunk of the tree on which the crow has settled, and make of it the daidalon; for this is the name that they give to the wooden image also. This festival the Plataians celebrate by themselves, calling it the Little Daidala, but the Great Daidala, which is celebrated with them by the Boiotians, is a festival held with intervals of fiftynine years, for that is the period during which, they say, the festival could not be held, as the Plataians were in exile. There are fourteen wooden images ready, having been provided each year at the Little Daidala. Lots are cast for them by the Plataians, Koronaians, Thespians, Thangraians, Chaironeis, Orchomenians, Lebadeis, and Thebans. For at the time when Kassandros, the son of Antipater, rebuilt Thebes, the Thebans wished to be reconciled with the Plataians, to share in the common assembly, and to send a sacrifice to the Daidala. The towns of less account pool their funds for images. Bringing the image to the Asopos, and setting it upon a wagon, they place a bridesmaid also on the wagon. They again cast lots for the position they are to hold in the procession. After this they drive the wagons from the river to the summit of Kithairon. On the peak of the mountain an altar has been prepared, which they make in the following way. They fit together quadrangular pieces of wood, putting them together just as if they were making a stone building, and having raised it to a height they place brushwood upon the altar. The cities with their magistrates sacrifice a cow to Hera and a bull to 
Zeus, burning on the altar the victims, full of wine and incense, along with the daidala. Rich people, as individuals sacrifice what they wish; but the less wealthy sacrifice the smaller cattle; all the victims alike are burned. The fire seizes the altar and the victims as well, and consumes them all together. I know of no blaze that is so high, or seen so far as this (transl. by W.H.S. Jones, modified).

\section{BIBLIOGRAPHY}

Aravantinos, V., Mycenaean Place-Names from Thebes, Minos 20-22 (1987) 33-40. Avagianou, A., Sacred Marriage in the Rituals of Greek Religion (Bern-Berlin-FrankfurtNew York 1991).

Béquignon, Y., La vallée du Spercheios des origines au $I V^{e}$ siècle. Études d'archéologie et de topographie (Paris 1937).

Bierl, A., Karion, die Karer und der Plutos des Aristophanes als Inszenierung eines anthesterienartigen Ausnahmefestes, in: A. Bierl, P. von Möllendorff (eds.), Orchestra. Drama, Mythos, Bühne. Festschrift für Hellmut Flashar anlässlich seines 65. Geburtstages (Stuttgart-Leipzig 1994) 30-43.

Bonnechere, P., Le sacrifice humain en Grèce ancienne (Athens-Liège 1994).

Brelich, A., Paides e parthenoi (Rome 1969).

Bruit, L., The Meal at the Hyakinthia: Ritual Consumption and Offering, in: O. Murray (ed.), Sympotica. A Symposium on the Symposion (Oxford 1990) 162-174.

Brulé, P., Fêtes grecques: Périodicité et initiations. Hyakinthies et Panathénées, in: A. Moreau (ed.), L'initiation. Actes du colloque international de Montpellier 11-14 avril 1991 (Montpellier 1992) I 19-38.

Burkert, W., Structure and History in Greek Mythology and Ritual (Berkeley-Los AngelesLondon 1979) 132-134.

- Homo Necans. The Anthrapology of Ancient Greek Sacrificial Ritual and Myth (BerkeleyLos Angeles-London 1983; translated by P. Bing).

- , Greek Religion (Cambridge, Mass. 1985).

- Katagógia-Anagógia and the Goddess of Knossos, in: R. Hägg, N. Marinatos, G. Nordquist (eds.), Early Greek Cult Practice. Proceedings of the Fifth International Symposium at the Swedish Institute at Athens, 26-29 June, 1986 (Stockholm 1988) 81-87.

Calame, C., Thésée et l'imaginaire athénien (Lausanne 1990).

Chaniotis, A., Gedenktage der Griechen: Ihre Bedeutung für das Geschichtsbewußtsein griechischer Poleis, in: J. Assmann (ed.), Das Fest und das Heilige. Religiöse Kontrapunkte zur Alttagswelt (Gütersloh 1991), 123-145.

- Die Geschichte von Amnisos von Homer bis zur Eroberung Kretas durch die Türken, in: J. Schäfer (ed.), Amnisos nach den archäologischen, topographischen, historischen und epigraphischen Zeugnissen des Altertums und der Neuzeit (Berlin 1992) 73-127.

- - Sich selbst feiern? Die städtischen Feste des Hellenismus im Spannungsfeld zwischen Religion und Politik, in: P. Zanker, M. Wörrle (eds.), Stadtbild und Bürgerbild im Hellenismus (Munich 1995) 147-172.

Clark, I., The Gamos of Hera. Myth and Ritual, in: S. Blundell, M. Williamson (eds.), The Sacred and the Feminine in Ancient Greece (London 1998) 13-26.

Detienne, M., The Violence of Wellborne Ladies: Women in the Thesmophoria, in: M. Detienne, J.-P. Vernant (eds.), The Cuisine of Sacrifice among the Greeks (ChicagoLondon 1989; translated by P. Wissing) 129-147.

Deubner, L., Attische Feste (Berlin 1966; second edition).

Farnell, L.R., The Cults of the Greek States. Vol. I (Oxford 1896). 
Frazer, J.G., The Golden Bough. A Study in Magic and Religion. Part I. The Magic Art and the Evolution of Kings. Volume II (London ${ }^{3} 1913$ ).

Frontisi-Ducroux, F., Dédale. Mythologie de l'artisan en Grèce ancienne (Paris 1975).

Furley, W.D., Studies in the Use of Fire in Ancient Greek Religion (New York 1981).

Graf, F., Zeichenkonzeption in der Religion der griechischen und römischen Antike, in: R. Posner, K. Robering, T.A. Sebeok (eds.), Semiotik. Ein Handbuch zu den zeichentheoretischen Grundlagen von Natur und Kultur (Berlin-New York 1997) 939 958.

Jaccottet, A.-F., Le lierre de la liberté, ZPE 80 (1990) 150-156.

Jacoby, F., Die Fragmente der griechischen Historiker. Dritter. Teil. Kommentar (Leiden 1955).

Jeanmaire, J., Couroi et Couretes. Essai sur l'education spartiate et sur les rites d'adolescence dans l'antiquité classique (Lille 1939).

Jost, M., Le thème des disputes entre Héra et Zeus en Arcadie et en Béotie, in: Héra. Images, espaces, cultes. Actes du Colloque International de Lille (Naples 1997) 87-92.

Kennell, N.M., The Gymnasium of Virtue: Education and Culture in Ancient Sparta (Chapell Hill-London 1995).

Kerényi, K., Zeus und Hera. Urbild des Vaters, des Gatten und der Frau (Leiden 1972).

Kern, O., Die Religion der. Griechen. Erster Band. Von den Anfängen bis Hesiod (Berlin 1926).

Kirsten, E., Plataiai, RE XX.2 (1950) $2255-2332$.

Knoepfler, D., La réorganisation du concours des Mouseia à l'époque hellénistique: esquisse d'une solution nouvelle, in: A. Hurst, A. Schachter (eds.), La Montagne des Muses (Geneva 1996) 141-167.

Kossatz-Deissmann, A., Hera, in: Lexicon Iconographicum Mythologiae Classicae (ZurichMunich 1988) IV 659-719.

- Semele, in: Lexicon Iconographicum Mythologiae Classicae (Zurich-Munich 1994) VII $718-726$.

Lambert, S.D., The Phratries of Attica (Ann Arbor ${ }^{2}$ 1998).

Leitao, D.D., The Perils of Leukippos: Initiatory Transvestism and Male Gender Ideology in the Ekdusia of Phaistos, ClAnt 14 (1995) 130-163.

Loucas-Durie, E., Simulacre humain et offrande rituelle, Kemos I (1988) 151-162.

Ma, J., Black Hunter Variations, PCPS 40 (1994) 49-80.

Meuli, K., Griechische Opferbräuche, in: O. Gigon et alii (eds.), Phyllobolia fuir Peter von der Mühll zum 60. Geburtstag am 1. August 1945 (Basel 1946) 185-287 = Gesammelte Schriften (Basel 1975) II 907-1018.

Nafissi, M., Zeus Basileus di Lebadea. La politica religiosa del koinon beotico durante la guerra cleomenica, Klio 77 (1995) 149-169.

Nilsson, M.P., Griechische Feste von religiöser Bedeutung mit Ausschluß der attischen (Lund 1906).

__., Geschichte der griechischen Religion. 1. Die Religion Griechenlands bis auf die griechische Weltherrschaft (Munich ${ }^{3}$ 1967).

Parker, R., Athenian Religion: A History (Oxford 1996).

Pettersson, M., Cults of Apollo at Sparta: The Hyakinthia, the Gymnopaidiai, and the Kameia (Stockholm 1992).

Pötscher, W., Hera. Eine Strukturanalyse im Vergleich mit Athena (Darmstadt 1987).

Prandi, L., L'Heraion di Platea e la festa di Daidala, in: M. Sordi (ed.), Santuari e politica nel mondo antico (Milan 1983) 82-94.

Robertson, N., A Point of Precedence at Plataia. The Dispute between Athens and Sparta over Leading the Procession, Hesperia 55 (1986) 88-102.

Roesch, P., Thespies et la confedération béotienne (Paris 1965).

Schachter, A., Cults of Boiotia. Volume 1. Acheloos to Hera (London 1981).

Simon, E., Hera und die Nymphen. Ein böotischer Polos in Stockholm, RA (1972) 205-220.

- Götter der. Griechen (Munich ${ }^{2} 1980$ ).

—- Héra en Béotie et en Thessalie, in: Héra. Images, espaces, cultes. Actes du Colloque International de Lille (Naples 1997) 83-86. 
Sokolowski, F., Lois sacrées des cités grecques. Supplément (Paris 1962).

, Lois sacrées des cités grecques (Paris 1969).

Stengel, P., Opferbräuche der Griechen (Leipzig-Berlin 1910).

Sümeghy, V., Die Wagengefässe und das Daidalafest, in: Atti del VII Congresso Internazionale di Archaeologia Classica (Rome 1961) III 125-133.

Versnel, H.S., Inconsistencies in Greek and Roman Religion, II. Transition and Reversal in Myth and Ritual (Studies in Greek and Roman Religion 6, II, Leiden 1993, ${ }^{2} 1994$ ).

Waldner, K., Geburt und Hochzeit des Kriegers. Geschlechterdifferenz und Initiation in Mythos und Ritual der griechischen Polis (Berlin-New York 2000).

Wilamowitz-Moellendorf, U. von, Der Glaube der Hellenen (Berlin 1931). 